\title{
Toestande in die Unie van Suid-Afrika op die vooraand van die Eerste Wêreldoorlog
}

\begin{abstract}
Although the act of violence precipitating the First World War came unexpectedly, it was evident even before the turn of the century that thunder clouds were gathering across Europe and consequent events pointed to eventual conflict. The article below deals with the situation in the Union of South Africa on the eve of the First World War.
\end{abstract}

Op 28 Junie 1914 word die Oostenrykse troonopvolger, aartshertog Frans Ferdinand en sy vrou, Sophia, in die Bosniese dorpie Sarajevo deur 'n sluipmoordenaar met twee rewolwerskote om die lewe gebring. Hierdie daad laat die Europese kruitvat ontplof en ontketen 'n oorlog wat nie net tot Europa beperk bly nie, maar volkere en nasies van oor die aardbol daarby betrek. Ook die Unie van Suid-Afrika word nie die geweld van oorlog gespaar nie, maar in die maalstroom van oorlogsgebeure ingesuig.

Die gewelddaad wat die oorlog gepresipiteer het, was wel onverwags, maar reeds voor die wenteling van die eeu was die oorlogswolke besig om oor die Europese volkeregemeenskap saam te pak en het gebeure op ' $n$ uiteindelike konflik heengewys. Sommige van die onderliggende oorsake, wat die nodige klimaat vir hierdie katastrofiese gebeurtenis geskep het, het so ver soos die Heilige Romeinse Ryk van Karel die Grote teruggereik. Ander weer kon net onder die oppervlakte van die huidige politieke, militêre, ekonomiese en sosiale omstandighede in Europa gevind word: onversadigde nasionale strewes, imperiale en ekonomiese konkurrensie, ' $n$ bewapeningswedloop en magsgroeperinge.

Tot 1890 het Brittanje hom eerder op die konsolidasie van sy ryk en die uitbouing van internasionale handelskontakte toegespits as om by die twiste van die nasies van die vasteland betrokke te raak. Solank Brittanje sy beleid van "splendid isolation" gehandhaaf en hom nie by die Europese bondgenootskappe laat betrek het nie, kon die wankele vrede nog gehandhaaf word. Die Britse buitelandse betrekkinge sou egter veral ná 1890 'n heraanpassing ondergaan. In hierdie jaar is Otto von Bismarck, die Duitse Kanselier, deur George von Caprivi vervang en sou laasgenoemde, én sy opvolgers, veral onder die invloed van die jong keiser Wilhelm II, wegbuig van ' $n$ Kontinentale Politiek en dit met ' $n$ doelgerigte Weltpolitik vervang. Duitsland, die eertydse klant, het nou ook begerige oë op die internasionale handel en kolonies begin rig en Brittanje se grootste nywerheids- en handelsmededinger geword. Dit was ook vir Brittanje duidelik dat sy oppermag ter see, en daardeur sy hele Ryk, kort voor lank deur Duitsland bedreig sou word indien hy nie sy skeepsbouprogram versnel nie, wat geweldige uitgawes sou meebring. Die verhouding tussen dié twee lande het vinnig op openlike vyandskap afgestuur. Dit is dan ook nie vreemd dat Brittanje bondgenote begin soek en hom in 1904 laat betrek het by die Enténte met Frankryk en Rusland nie. Hierteenoor het die ander Europese magsblok onder leiding van Duitsland, met Oostenryk en Italië as mede-bondgenote, $\mathrm{nl}$ die Drievoudige Verbond, stelling ingeneem.

Toe die moord op aartshertog Frans Ferdinand op 1 Augustus 1914 tot ' $n$ oorlogsverklaring van Duitsland teen Rusland, en op 3 Augustus teen Frankryk lei, het dit Engeland nie vanselfsprekend by die oorlog betrek nie - die skending deur Duitsland van Belgiese neutraliteit sou later daarvoor verantwoordelik wees. Die uitvoering van die Schlieffen-meesterplan deur die Duitse leër, wat daarop gemik was om Frankryk binne ses weke uit te klop, voordat Rusland sy mobilisasie kon voltooi, het Duitse troepebewegings deur België genoodsaak. Die skending van Belgiese neutraliteit, wat die integriteit van die Britse suidkus in gedrang gebring het, het Britse toetrede tot die oorlog, volgens die Britse regering se siening, onvermydelik gemaak. Op $4 \mathrm{Au}-$ gustus het Brittanje dus oorlog teen Duitsland verklaar, ook namens die Britse Ryk (insluitende die Unie van Suid-Afrika).

Toe die Britse ultimatum aan Duitsland die aand van 4 Augustus verstryk, was Suid-Afrika, as deel van die Britse Ryk, outomaties by die oorlog betrokke, omdat die konstitusionele status van die dominiums neutraliteit vir hulle uitgesluit het. ${ }^{1}$ Tydens samesprekings van die Committee of Imperial Defence in Mei 1911 in Londen, het die afgevaardigdes na die Imperiale Konferensie 
hierdie beginsel eenparig onderskryf.. ${ }^{2}$ Die Kanadese premier, sir Wilfred Laurier, het egter gekonstateer dat die omvang (indien enige) van hulle aktiewe deelname aan ' $n$ oorlog, ' $n$ aangeleentheid was wat alleen deur die dominiale parlemente beslis kon word. Met hierdie standpunt het die Britse regering nie ernstig verskil nie. ${ }^{3}$

Die Unie-afgevaardigdes het nie aan die debat hieroor deelgeneem of sterk standpunt ingeneem nie. ${ }^{4}$ Die standpunt van die dominiale afgevaardigdes by hierdie konferensie het egter hulle regerings geensins, behalwe in 'n morele sin, gebind nie, want soos die Britse premier, Asquith, tereg aangetoon het: "The Committee of Imperial Defence is a purely advisory body. Neither the Government of the United Kingdom, nor of course, the Governments of any of the Dominions are in the least committed by any of its decisions ..."

Die Britse regering het toe die internasionale situasie kritiek begin word, dit sy plig geag om die Unieregering op 29 Julie en 1 Augustus hieroor in te lig en te waarsku. Die Unieparlement was in hierdie stadium nie in sitting nie en ook die premier, genl. Louis Botha, was nie byderhand nie, want hy was in Rhodesië op pad na die Kongo-gebied en het haastig na Pretoria teruggekeer. $^{6}$

Op 4 Augustus reageer die Unieregering op die tydige waarskuwings van die Imperiale Regering deur aan te bied om verantwoordelikheid te aanvaar vir die pligte wat dusver toegewys is aan die imperiale garnisoen in die Unie: "The Government fully recognising the obligations of the Union, in the event of hostilities, wishes to assure you of its preparedness to take all such measures as may be necessary for the defence of the Union. Should His Majesty's Government require the Imperial Troops, now stationed in South Africa and who are not connected with the garrison artillery, in any part of the world, Ministers would gladly employ the defence force of the Union for the performance of the duties entrusted to the Imperial Troops in South Africa." ${ }^{7}$

Op 6 Augustus het Lewis Harcourt, die Britse Staatsekretaris vir Kolonies, nie alleen met dank Botha se aanbod aanvaar nie, maar met die versoek gekom dat: "If your Ministers at the same time desire and feel themselves able to seize such part of German South West Africa as will give them the command of Swakopmund, Lüderitzbucht and the wireless stations there or in the interior, we should feel that this was a great and urgent Imperial service. You will however realize that any territory now occupied must be at the disposal of the Imperial Government for purposes of an ultimate settlement at the conclusion of peace. Other Dominions are acting in a similar way on the same understanding."

Terwyl die Unieregering nog besig was om hierdie boodskap te oorweeg is ' $n$ tweede, nog dringender, versoek van Harcourt op 9 Augustus ontvang: "My telegram of 6th August. His Majesty's Government regard as urgent necessity seizure of coast wireless stations at Swakopmund and Lüderitzbucht; this can only be effected in reasonable time by a joint Naval and Military expedition up the coast. Capture of long distance station Windhoek, which is of great importance, might follow another expedition against coast stations or be carried out independently from interior, but this must rest with your Government."

Daar was om die volgende verskillende oorwegings vir hierdie dringende versoek van die Britse regering:

1. Dat Duits-Suidwes-Afrika die enigste Duitse kolonie was wat 'n gemeenskaplike front met 'n Britse besetting gehad het en wat reeds ' $n$ geruime tyd, na die oordeel van die Britse amptenare, ' $n$ bedreiging vir die Unie, as ' $n$ skakel in die imperiale ketting, gevorm het. ${ }^{10}$ Hierdie vrees is vererger deur die feit dat daar baie van die bittereinder Kaapse rebelle in Duits-Suidwes-Afrika woonagtig was, wat in die Tweede Vryheidsoorlog geveg het en nie hulle republikeinse ideale wou afsweer nie. ${ }^{11}$

2. 'n Sub-komitee van die Committee of Imperial Defence het op 5 Augustus aanbeveel dat offensiewe operasies deur die plaaslike magte teen die Duitse kolonies in Afrika en in die Stille Oseaan onderneem moet word en dat dit die volgende dag deur die Britse kabinet aanvaar is. ${ }^{12}$ Daar is egter geen plan vir operasies teen die Duitse kolonies voor Augustus 1914 opgestel, soos veelal vermoed en beweer is nie. ${ }^{13}$

3. ' $n$ Verdere oorweging is ook genoem in die sub-komitee se aanbevelings: die verowering van Duits-Suidwes-Afrika word vir die politieke effek daarvan aangemoedig om sodoende die samewerking van die Suid-Afrikaanse regering te verkry. 
Spies meen dat die faktore hierbo genoem wat spesifiek op Duits-Suidwes-Afrika betrekking gehad het, op sy beste, sekondêr was, want al sou hulle ontbreek het, sou die Britse regering nog steeds die verowering van daardie Duitse kolonie aangemoedig het omdat die voorgestelde veldtog deel was van 'n groter skema wat ses koloniale ekspedisies behels het. ${ }^{15}$

Die amptelike beweegrede vir die omvattende koloniale operasies was om die Duitse vloot van sy koloniale basisse sowel as sy radiostasies te beroof. Toe vyandelikhede begin, was die Britse regering ook begerig om die Duitse kolonies te annekseer sodat hulle by vredesonderhandelinge as "diplomatieke gyselaars" of as troefkaarte gebruik kon word. ${ }^{16}$ Hierdie motief blyk uit die telegram van 7 Augustus aan die Unieregering waarin dit gestel word dat enige gebied wat in die oorlog verower word vir 'n uiteindelike skikking aan die einde van die oorlog beskikbaar moet wees. ${ }^{17}$

Die Uniekabinet het op Vrydag 7 Augustus vergader en Botha se onbenydenswaardige taak was om sy ministers te oorreed om positief teenoor die versoek op te tree. Daar was geen eensgesindheid onder die kabinetslede oor die aangeleentheid nie en hoewel daar nie gestem is nie, was dit duidelik dat slegs 'n geringe meerderheid ten gunste daarvan was. Smuts (Minister van Verdediging en Finansies en waarnemende Minister van Binnelandse Sake), sir Thomas Watt (Minister van Pos en Telegrafie en Openbare Werke), N.J. de Wet (Minister van Justisie) en $\mathrm{H}$. Burton (Minister van Spoorweë en Hawens) het Botha ondersteun, hoewel Burton verklaar het dat as dit nie vir die Britse versoek was nie, die Kabinet nie uit sy eie so 'n stap sou oorweeg het nie. Vier Afrikaanssprekendes, te wete, F.S. Malan (Minister van Mynwese, Industrieë en Opvoeding), H.C. van Heerden (Minister van Landbou), H.S. Theron (Minister van Lande) en J.A.C. Graaff (Minister Sonder Porfolio) was téén Botha se standpunt gekant. ${ }^{18}$

Malan was van oordeel dat die regering se onderneming op 4 Augustus ver genoeg gegaan het. Hy het veral daaroor beswaard gevoel omdat die inwoners van Duits-Suidwes-Afrika geen aanval op die Unie gebied gemaak het nie; die Unie al sy magte teen moontlike opstand van sy eie inboorlinge nodig gehad het; die SuidAfrikaanse Party alreeds verdeel was en dit gevolglik onwenslik sou wees om die lojaliteit van die bevolking verder te beproef as wat dit in die telegram van 4 Augustus voorgestel is en die veldtog praktiese probleme sou oplewer weens die woestynagtige aard van die terrein en die feit dat Suid-Afrika nie ' $n$ vloot gehad het om ' $n$ aanval van die see se kant af te loods nie. Hy was van oordeel dat die Unieregering slegs spoor-en telegraaffasiliteite tot beskikking van die imperiale outoriteite moes stel en dat hy eerder sy eie land moes verdedig. Hy het aangedui dat hy geen agitasie teen Brittanje sou ondersteun nie, maar as die meerderheid van die ministers ten gunste van die ekspedisie was, sou hy uit die kabinet bedank. Hierop het die kabinet verdaag en dit sou nie voor 10 Augustus wees dat Botha daarin sou slaag om die eenparige steun van die Kabinet te verkry nie. ${ }^{19}$

Op die volgende kabinetsvergadering, op $8 \mathrm{Au}$ gustus, het Malan weer dieselfde besware geopper. Hy het nog ' $n$ verdere punt bygevoeg, naamlik, dat weens die voorwaarde deur die Britse regering gestel dit nie eers moontlik is om daarop aanspraak te maak dat die doel van die ekspedisie is om Duits-Suidwes-Afrika te annekseer nie. ${ }^{20}$

Op Sondag 9 Augustus het ministers Malan, Graaff en Van Heerden mekaar ontmoet en hoewel hulle steeds teen die onderneming gekant was, het dit voorgekom of Malan se teenstand besig was om te verswak. Graaff het hom egter ingelig dat die waarnemende Goewerneur-generaal, lord De Villiers, in die huidige omstandighede ook nie ten gunste van die Suidwes-ekspedisie was nie. ${ }^{21}$ Daardie aand het Botha vir Malan persoonlik gaan spreek en hom meegedeel dat indien die regering weier om DuitsSuidwes-Afrika binne te val, dit die Engelssprekende Suid-Afrikaners van hulle Afrikaanssprekende landgenote sou vervreem, terwyl oorlog teen 'n gemeenskaplike vyand sou meehelp om Engelse en Afrikaanse burgers nader aan mekaar te bring. Hierdie argument het Malan egter nie heeltemal oortuig nie. Hy teken in sy dagboek aan: "Een pragtige poltiek doch hij loopt gevaar om onder sekere voorwaardes tot die inval van DSWA toe te stem." 22

Die volgende dag het Botha die telegram van 9 Augustus $^{23}$ aan sy ministers voorgelees en 'n beroep op Malan gedoen om saam te werk. Smuts het ook die twyfel oor die wysheid van 'n positiewe reaksie op die Britse versoek probeer besweer, deur te sê dat die ekspedisiemag uit vrywilligers sou bestaan. Malan het hierop ingestem om Botha se voorstelle te steun op vóór- 
waarde dat geen burgers vir die veldtog opgekommandeer word nie en dat die parlement eers geraadpleeg word. Toe die invloedrykste ministers saamstem, het die ander hulle gevolg en is Malan en Smuts aangestel om die antwoord aan Harcourt op te stel. Volgens Malan het die regering in die oorspronklike formulering van die antwoord ingestem om die veldtog te onderneem mits die parlement dergelike optrede eers goedkeur en daar is ook gekonstateer dat vrywilligers eers gebruik sou word. Malan beweer dat die aanvanklike konsep gewysig is. In die finale vorm is daar duidelik gestipuleer dat die vlootgedeelte van die veldtog deur die Imperiale Gesaghebbers onderneem sou word en die verwysing na parlementêre goedkeuring daaruit weggelaat is as synde onnodig. Die antwoord van 10 Augustus was dus 'n onvoorwaardelike aanvaarding van die Britse voorstel sonder verwysing na die parlement of vrywilligers. ${ }^{24}$

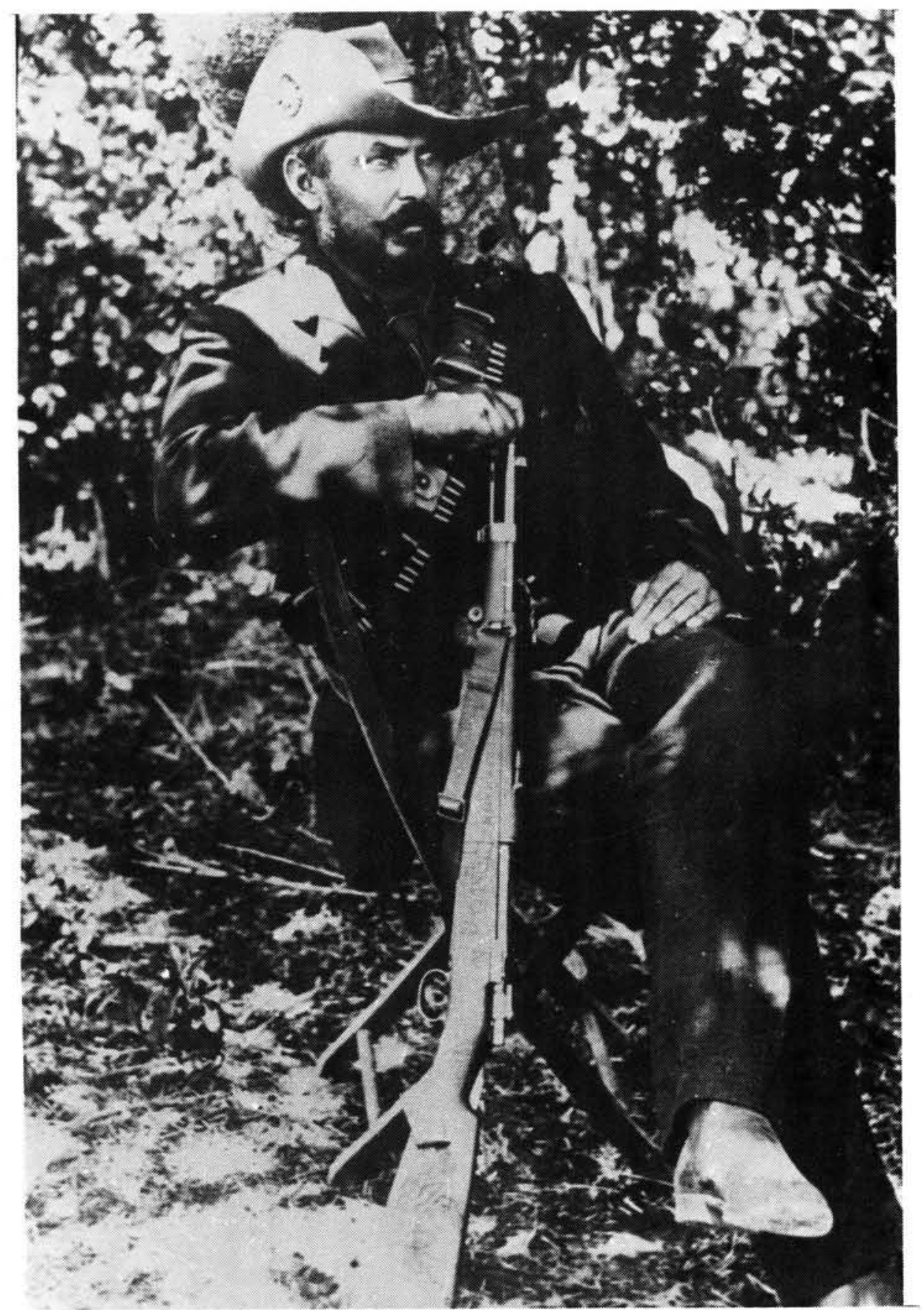

Genl Louis Botha 


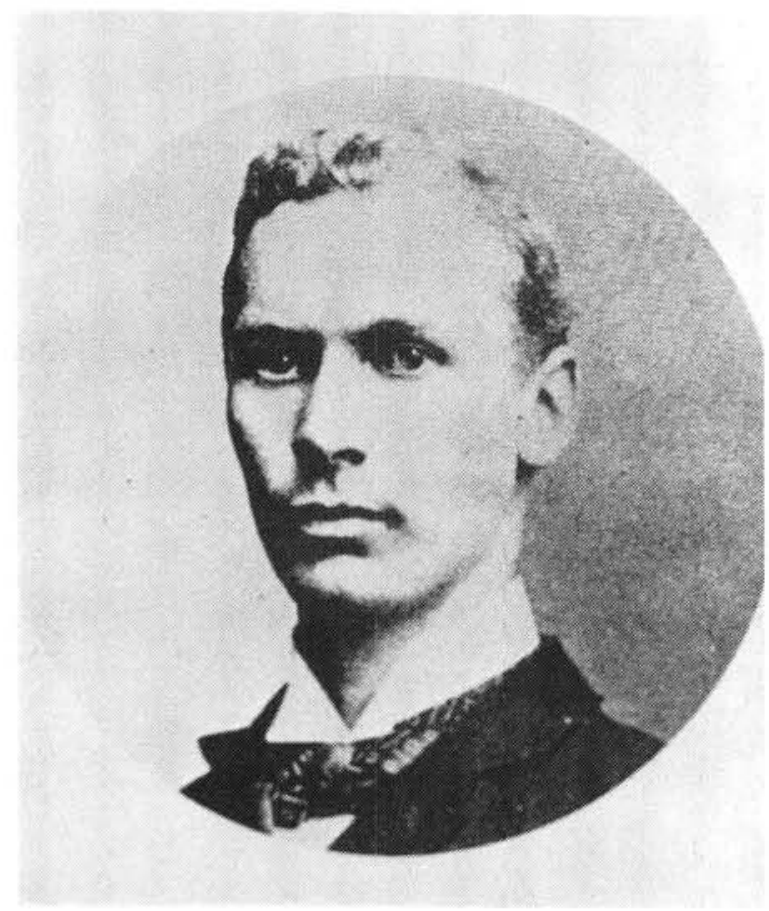

Genl Jan Smuts

Daar is ook deur die Kabinet ooreengekom dat die Parlement byeengeroep sou word vir ' $n$ spesiale sitting wat op 9 September sou begin. Agterna in 1916 het Botha beweer dat hulle besluit het om die taak in Suidwes-Afrika ten uitvoer te bring op één voorwaarde: dat hulle niks sal doen voordat hulle nie eers die parlement byeengeroep het nie en dié dit goed- of afkeur nie. ${ }^{25}$

In werklikheid is uitgebreide militêre stappe ter voorbereiding vir die veldtog reeds voor 9 September gedoen. Middel Augustus is ' $n$ aantal van die Aktiewe Burgermag-eenhede opgeroep vir diens "enige plek in Suid-Afrika, binne of buite die Unie." ${ }^{26}$ Die militêre planne vir die veldtog is op 21 Augustus gefinaliseer en op 1 September is ' $n$ mag wat deur brigadier Lukin ${ }^{27}$ aangevoer is, by Port Nolloth aan wal gebring om teen die suidgrens van die Duitse kolonie op te tree. Daar was ook die verdere voorneme dat die mag wat Lüderitzbucht sou aanval, Kaapstad sou verlaat voordat die parlement 'n besluit neem. Daar was egter ' $n$ vertraging omdat geen vlootkonvooie beskikbaar was nie. ${ }^{28}$

Botha het later erken dat: "We are going ahead with the expedition before Parliament had decided. In case Parliament did not agree with our policy, then of course we would not remain in office any longer. We would have resigned and the expedition would have been recalled." 29
Spies merk tereg op dat dit baie moeilik sou gewees het om die ekspedisie te herroep as die invalsmag alreeds in gevegte met die Duitsers betrokke was. ${ }^{30}$

Hoewel Botha nou die ondersteuning van sy ministers gehad het en ook geweet het dat hy op die Unioniste party, en moontlik ook die Arbeiderparty, kon reken, moes hy nog steeds seker maak dat sy gewone volgelinge in die parlement sou toestem tot die inval in Duits-Suidwes-Afrika. $\mathrm{Hy}$ het ook besef dat dit nie maklik sou gaan nie. Benewens die teenstand wat hy in die Kabinet ervaar het, was dit duidelik dat daar wydverspreide teenstand binne Afrikanergeledere teen die veldtog was, alhoewel daar geen openbare aankondiging van die regering se voorneme plaasgevind het nie. ${ }^{31}$

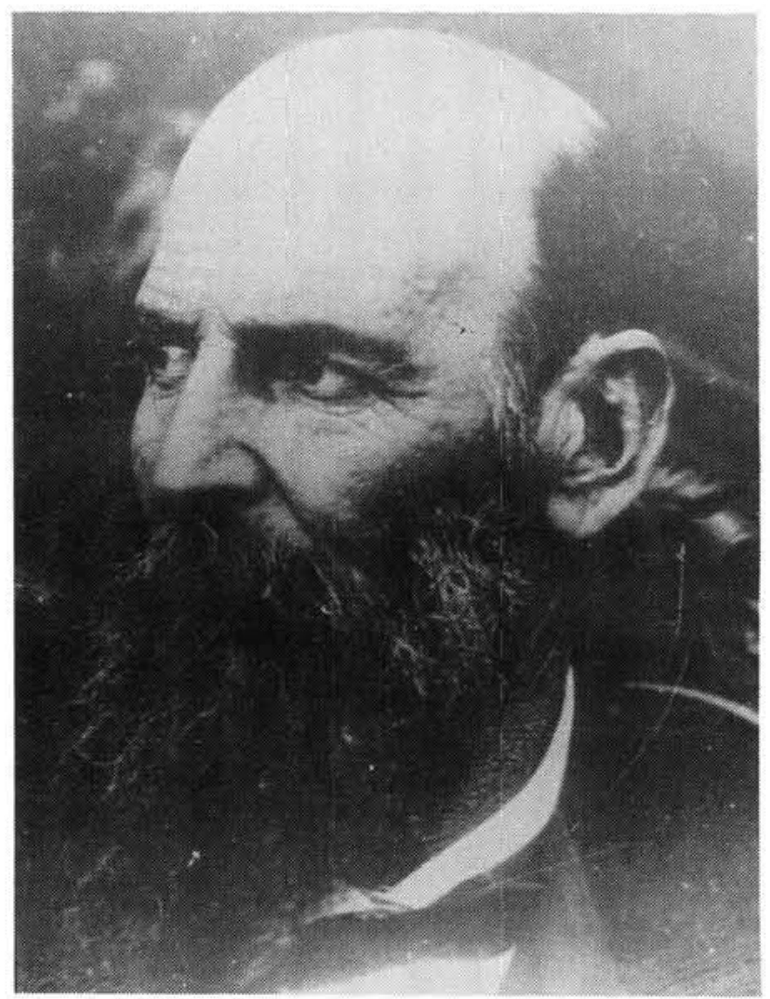

Genl J.H. de la Rey

Teen die middel van Augustus het 'n groot aantal mense van die veldtog geweet, of vermoed dat dit gaan plaasvind. C.F. Beyers, die Kommandant-generaal van die Unie-verdedigingsmag het sy afkeur daarvan te kenne gegee toe hy kort na 10 Augustus van die regering se planne in kennis gestel is. Generaal J.H. de la Rey, wat 'n regeringsenator was, het Botha en Smuts gewaarsku teen die ernstige gevolge van hulle voorgenome inval in Duits-Suidwes-Afrika. 
Daar was eweneens 'n besliste gevoel téén die veldtog onder sekere Transvaalse kommandante wat ' $n$ vergadering in Pretoria op 14 Augustus bygewoon het - selfs al het Botha en Smuts probeer verhoed dat die veldtog bespreek word. ' $n$ Mosie téén die veldtog is ook op die Transvaalse Kongres van Nasionale Party op 26 Augustus aanvaar. ${ }^{32}$ Dit was eweneens ' $n$ fout dat Botha nie vir Hertzog in sy vertroue geneem het en van die wenslikheid vir die Unie van die Duits-Suidwes-Afrika-veldtog oortuig het nie. Hy het wél die ander twee opposisieleiers vroeër ingelig, maar vir Hertzog geïgnoreer. ${ }^{33}$ Daar bestaan goeie rede om te vermoed dat Botha hom reeds veel vroeër moreel verbind het om DuitsSuidwes-Afrika binne te val vir geval 'n oorlog tussen Engeland en Duitsland uitbreek. Lloyd George, latere Eerste Minister van Brittanje tydens die oorlog, het getuig dat Botha reeds tydens die Imperiale Konferensie van 1911 aan hom gesê het dat indien oorlog sou uitbreek, "I will keep my word and stand by the Empire. As soon as war is declared I will lead 40000 horsemen into German South West Africa and clear out the Germans." 34

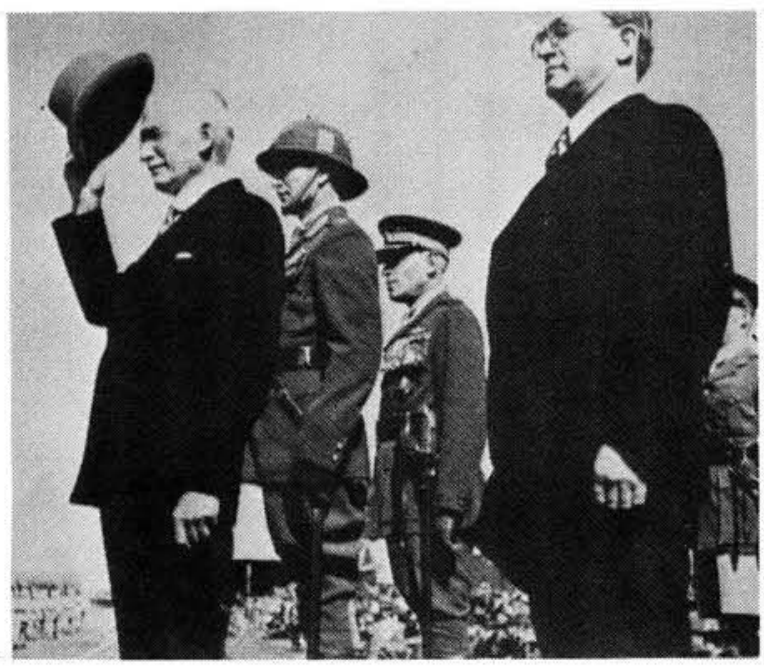

\section{Genl J.B.M. Hertzog, Eerste Minister van Suid-Afrika by die uitbreek van die Tweede Wêreldoorlog, tydens 'n vooroorlogse parade wat te Swartkop naby Pretoria gehou is.}

Louis Botha en genl. Hertzog, leier van die Nasionale Party, het wyduiteenlopende menings gehuldig oor die rol wat die Unie in die oorlog moes speel, maar tog op dié een punt saamgestem: dat Suid-Afrika ipso facto in 'n staat van oorlog verkeer het indien Brittanje in een betrokke raak. ${ }^{35}$ Die Unie van Suid-Afrika was 'n integrale deel van die Empire en wanneer oorlog in Londen verklaar word, was elke deel van die
Britse Ryk outomaties betrokke. Konstitusioneel het Suid-Afrika geen keuse gehad nie. Dit was ook die houding van Botha en sy regering. Vir hom was die koning in ' $n$ oorlog betrokke en derhalwe was dié se vyande ook die Unie s'n. ${ }^{36}$

Op Leeuwpoort in die kiesafdeling Losberg, het Botha dit duidelik gestel dat hoewel die Dominiums oor die reg beskik het om te besluit of hulle buite hulle eie gebied wil gaan veg, hulle nie neutraal kon staan in 'n oorlog waarin Engeland betrokke is nie. ${ }^{37}$

Die minste wat die Unie dus as selfregerende Dominium kon doen, was om na sy eie verdediging om te sien.

Die kwessie van die Unie se betrokkenheid by die oorlog sou die politieke twis tussen die Botha - en Hertzog-faksies op die spits dryf, want die verskil tussen hulle was só fundamenteel dat dit nie oorbrug kon word nie. ${ }^{38}$

Botha het dit as sy lewenstaak beskou om die kloof wat tussen Afrikaanssprekendes en Engelssprekendes bestaan het, te oorbrug. ${ }^{39}$ Hierdie gesindheid van die Premier het - beslis in hoofsaak - sy beslag gekry toe Verantwoordelike Bestuur in 1906 en 1907 aan die OranjeVrystaat en Transvaal geskenk is. In sy toespraak as premier van die Transvaal het Botha hom soos volg uitgelaat: "Een gevoel van diepe dankbaarheid bezielt de bevolking want de koning van Engeland, de Britse Regering en de Britse volk hebben de gehele bevolking der Transvaal vertrouwd op een wyze dat geen weerga vindt in de geschiedenis. Het gevolg is dat vele mannen, die 5 jaar geleden een voornaam aandeel in de oorlog namen, vandag Britse ministers zijn. Is het mogelyk voor de Boeren een zo groot daad van edelmoedigheid en rechtvaardigheid te vergeten. Nooit, als er ooit goed gezaaid is in Zuid-Afrika, dan is het in deze vrye konstitusie. ${ }^{40 "}$

Die Unie se premier het dan ook al hoe meer toenadering tot Engeland gesoek en toegeneentheid teenoor dié land geopenbaar. Op hulle beurt het die Britte weer uit hulle pad gegaan om die goeie gesindheid en steun van dié eertydse vyand en Boeregeneraal te wen. Botha se besoek aan Engeland in 1907 en die wyse waarop hy en sy familie met eerbewys oorlaai is, sowel as die vleiende publisiteit aan hulle verleen, moes hom diep beïnvloed het. Hy is genoem: "The most popular and most admired man in England at the moment ... splendid justi- 
fication of Liberal Policy." Ook: "Hero of the occasion ... been advanced and praised as a fighting man ... he will be admired and praised infinitely more as leader in the path of peace and unity. ${ }^{41}$ Die metamorfose van Kommandantgeneraal téén die Britse Ryk tot Eerste Minister in daardie ryk is versinnebeeld deur die benoeming van Botha as lid van die Britse Geheime Raad en ere-generaal in die Britse leër. ${ }^{42}$ Laasgenoemde is ' $n$ onderskeiding wat in die reël slegs aan vorstelike persone toegeken is. $\mathrm{Na}$ aanleiding van sy aanstelling as Britse generaal skryf Botha aan Seeley, latere Minister van Oorlog in die Britse kabinet: "You would be surprised to see the effects of my conciliation policy and to witness the cordial co-operation between Briton and Boer today, and this is why I shall always remain grateful to you and the Liberal Party for the assistance that has been rendered and for the opportunity which has been given us to achieve what I can confidently say has been achieved today, viz peace between the white races in South Africa. "43

Wat die Afrikaanssprekende gedeelte van die bevolking betref, het sekere optredes van die Eerste Minister hulle teen die bors gestuit: sy skenking van die Cullinan-diamant aan Koning Eduard VII (1907); sy bereidwilligheid om die Britse vloot finansieel te steun; sy onthulling van die aartsimperialis, Cecil Rhodes, se standbeeld teen Tafelberg (1912); sy verbroedering met die Unioniste en sy afsydigheid teenoor die Afrikaanse taalbeweging. ${ }^{44}$ Daar is dus na Botha en Smuts as die hoëpriesters van versoening. verwys. ${ }^{45}$

Die eenheid wat met die totstandkoming van die Unie in die vooruitsig gestel is, het veral nie op politieke gebied geslaag nie, want Suid-Afrika was meer verdeeld as ooit tevore. Hierdie verdeeldheid sou verskerp word deur die uitbreek van die Eerste Wêreldoorlog. ${ }^{46}$ Dit is dus baie duidelik dat die uitbreek van die Europese oorlog op die mees ongeleë oomblik vir Suid-Afrika gekom het. Dit het té gou ná die unifikasieeksperiment gekom, want die volk was nie verenig nie. Dit het ook té gou na die politieke breuk in die geledere van die Afrikanerdom gekom en selfs té gou na die Tweede Vryheidsoorlog. SuidAfrika het gevolglik nie die wêreldkrisis as 'n verenigde nasie tegemoet gegaan nie, maar as een wat in homself verdeel was ${ }^{47}$ Dit sou die politieke klimaat help skep, waarbinne die Unie se oorlogspoging in Suidwes-Afrika sou ontplooi.
Behalwe die politieke breuk in Afrika-geledere was daar ook nog die twis tussen arbeiders en kapitaliste wat stakings in die spoorweë en wynbedryf tot gevolg gehad, waarin die regering moes tussenbeide tree, en die Indiërkwessie. Laasgenoemde verwys na die plasing van die immigrasiewet op die wetboek, wat die verdere binnekoms van Indiërs in die Unie onmoontlik gemaak het en hewige verset van die Indiërs uitgelok het. Daar was in hierdie omstandighede derhalwe geen samehorigheid onder die Uniebevolking en geen gesamentlike doelwit nie. Botha het besef dat die binnelandse toestand, in teenstelling met die ander dominiums, ingewikkeld en sorgwekkend was. ${ }^{48}$

Die Duits-Suidwes-Afrika-veldtog het Botha voor sy groot toets geplaas. Sy Engelssprekende volgelinge, soos die Unioniste, het gretig daarna uitgesien om met die Duitse vyand slaags te raak. Sy Afrikanervolgelinge, daarenteen, was lou en sonder geesdrif vir die saak. ${ }^{49}$ Die Nasionaliste was op hulle beurt weer vasbeslote om nie deel te neem aan so 'n militêre onderneming nie, want hulle het dit in belang van die Empire, nie van Suid-Afrika geag nie. Tereg is daar dus beweer: "The effect of the war was to transform the superficial political feelings into a deep seated hatred and bitterness." ${ }^{50}$

Teoreties het dit die Suid-Afrikaanse regering vrygestaan om die Britse versoek om operasies in Suidwes-Afrika te onderneem van die hand te wys, maar in die praktyk was dit moeilik vir Botha om nee te sê: Die Unie-premier het dan ook in die Volksraad beweer dat: "Their duty and their conscience told them to be faithful and true to the Imperial Government." ${ }^{51}$

Daar was ook bykomende oorwegings wat Botha gemotiveer het om Brittanje te help. Die moontlikheid van territoriale uitbreiding was 'n tema wat in sommige van sy toesprake en geskrifte groot aandag geniet het. ${ }^{52}$ Daarbenewens het hy toe hy die mosie vir die Unie-deelname op 12 September 1914 in die Senaat voorstel ook na die moontlikheid verwys dat Indiese of Australiese troepe gestuur sou word om operasies in Suidwes-Afrika te onderneem indien Suid-Afrika sy deelname weier. ${ }^{52}$ Daar is wel goeie rede om te glo dat die Britse regering troepe uit die Dominiums vir hierdie doel sou gebruik het indien Suid-Afrika geweier het. By twee geleenthede; gedurende die Rebellie en eenkeer toe dit wou voorkom asof die Suidwes-Afrika-veldtog nie na wense vorder nie het die Britse regering dit 
ernstig oorweeg om Australiese, Nieu-Seelandse of Britse magte na Suid-Afrika te stuur. ${ }^{54}$

Ten spyte van aansienlike opposisie teen Botha se voorgenome plan van aksie, selfs in sy eie koukus ${ }^{55}$ is die premier se mosie vir die Unie se deelname aan operasies teen Duits-SuidwesAfrika met 'n oorweldigende meerderheid, 91 stemme teen 12 in die Volksraad, en 24 teenoor 5 in die Senaat, aangeneem. ${ }^{56}$

Ten spyte van die groot parlementêre meerderheid was daar geen twyfel oor wat Smuts in 'n private brief aan F.X. Merriman genoem het nie: "the people's genuine dislike of the German South West Africa expedition. ${ }^{" 57}$ Hierdie ontevredenheid, wat 'n magdom van oorsake gehad het, sou kort hierna tot gewapende opstand lei.

*H.F. Nel (Kdoor-aftr) MA, Educ. HOD.

\section{Bibliografie}

1. Spies, S.B., "The Outbreak of the First World War and the Botha Government," Die SA Historiese Joernaal, No 1, p 47.

2. Die Unie van Suid-Afrika was verteenwoordig deur haar Eerste Minister, Louis Botha, die Minister van Opvoeding en Mynwese, F.S. Malan en die Minister van Pos en Telegrafie, sir David Graaff.

3. Asquith, H.H., The Genesis of War, p 116; Hankey, M., Supreme Command 1914-1918, p 130.

4. Malan, F.S., Aantekeningen Mei 1910 - September 1914, Indrukken van de Imperiale Konferentie 1911, Ongepubliseerde Dagboek (Kaapse Argief).

5. Asquith H.H., The Genesis of War, p 135. Kyk ook Hankey M., Supreme Command 1914-1918, p 131.

6. Walker, A.E., Lord de Villiers and his Times, p 499; Engelenburg, F.V. Genl Louis Botha, p 292.

7. A $2-15$, No 1, Ministers to Acting Governor General, Return laid upon the Table of the House of Assembly on the 11th March, 1915, of correspondence on the subject of the proposed naval and military expedition against German South West Africa.

8. A $2-15$, No 4, Acting Governor General to Ministers.

9. A 2-15, No 5, Secretary of State to Acting Governor General.

10. Louis, W.R., Great Britain and Germany's lost Colonies 1914-1918, p 31; Judd, D., Balfour and the British Empire, p 191.

11. UG 42-16, Judicial Commission of Inquiry into the Causes and Circumstances of the recent Rebellion in South Africa. Minutes of Evidence, $\mathrm{p} 73$.

12. Hankey, M.. The Supreme Command 1914-1918, pp 168-169; Guinn, P., British Strategy and Politics 1914-1918, p 41; Gifford, P. and Louis W.R. (eds) Britain and Germany in Africa, pp 275-76.

13. Hankey, M., The Supreme Command 1914-1918, pp 86-87; Seely, J.E.B., Adventure, p 139.

14. Smith, G., "The British Government and the Disposition of the German Colonies in Africa, 1914-1918" in Gifford, P and Louis, W.R., (eds) Britain and Germany in Africa, p 276.

15. Spies, S.B., "The Outbreak of the First World War and the Botha Government" etc $p 47$.

16. Smith, G., "The British Government etc" inf Gifford, $P$ and Louis, W.R., (eds) Britain and Germany in Africa, p 276.

17. A $2-15$, no 4, From Secretary of State to Acting Governor General.

18. Acc 583, F.S. Malan Versameling Mei 1910 - September 1914.

19. Ibid.
20. Spies, S.B., "The Outbreak of the First World War and the Botha Government etc, $p 50$.

21. Kyk Walker, E.A., Lord de Villiers and His Times: South Africa 1842-1914, p 504 .

22. Spies, S.B. "The Outbreak of the First World War and the Botha Government" etc, p 50; W.J. de Kock (red) SA Biografiese Woordeboek Deel I, p 520 .

23. UG 14-16, Bylae C, P 113.

24. Spies, S.B., "The Outbreak of the First World War and the Botha Government" etc pp 50-51.

25. Ibid, p 51; UG 42-16, p 350; Kyk ook Hancock, W.K. The Sanguine Years 1870-1919, p 380 en Davenport T.R.H.. The South African Rebellion, 1914, p 74.

26. UG 42-16, p 213; UG 46-16, p 7 .

27. In die geskrifte van daardie tyd word na die huidige rang van brigadiers in die SA Weermag as Brigadier-generaal verwys.

28. Spies, S.B., "The Outbreak of the First World War and the Botha Government" etc., p 51; UG 42-16, p 213; UG 46-16, p 7; Walker A.E., Lord de Villiers and his Times: South Africa 1842-1914, pp 503-7.

29. Spies, M.A., "The Outbreak of the First World War and the Botha Government" etc, p 51; UG 42-16, p 362

30. Ibid, p 56.

31. Ibid, p 51 ; kyk ook P.M. 359, Botha-Graaff.

32. Ibid, p 56; kyk ook Kemp, J.C.G., Die Pad van die Veroweraar, pp $137-144$

33. Marais, A.H., "Die Oorlogsbesluite, die Rebellie en die Nasionale Party" in Die Nasionale Party, Deel I, p 217.

34. Lloyd George, D., War Memoirs, D1 IV, p 1729; kyk ook Churchill, Randolph, S., Young Statesman 1901-1914, Vol II, p 17.

35. Spies, S.B., "The Outbreak of the First World War and the Botha Government" etc, p 47; Van den Heever, C.M., J.B.M. Hertzog, p 371.

36. Kruger, D.W., The age of the Generals, A short Political History of South Africa, $1910-1948, \mathrm{p} 80$.

37. Vriend des Volks, 29.9.1911.

38. Liebenberg, B.J., "Die Unie van Suid-Atrika en die Statuut van Westminister, 1910-1931" in Muller C.F.J., (red) 500 Jaar Suid-Afrikaanse Geskiedenis, pp 393-96.

39. Ibid, p 388

40. Die Volkstem, 13.3.1907

41. Spoelstra, B., "Die Bewindsaanvaarding van die Britse Regering oor Transvaal as Selfregerende Kolonie in 1907", Argiefjaarboek vir SuidAfrikaanse Geskiedenis, 16E, pp 366-67.

42. Crafford, F.S., Jan Smuts, p 105.

43. Seeley, J.E.B., Adventure, pp 154-155.

44. Liebenberg, B.J., "Die Unie van Suid-Afrika en die Statuut van Westminister, 1910-1931" in Muller, C.F.J. (red) 500 Jaar van Suid-Afrikaanse Geskiedenis, p 388.

45. Craftord, F.S., Jan Smuts, $p 98$

46. Van Jaarsveld, F.A., Van Riebeeck tot Verwoerd, p 256.

47. Kruger, D.W., The Age of the Generals, $p 87$.

48. Engelenburg, F.V., Louis Botha, p 292, Round Table 1916, p 584.

49. Kruger, D.W., The age of the Generals, $p 81$

50. Smuts, J.C.. War Times Speeches, 1917

51. Debates of both Houses of Parliament - Fifth and Extraordinary Session, 1914, col 58.

52. Hancock, W.K. en Van der Poel, J. (reds), Selections from the Smuts Papers (Botha-Reitz) p 198; Botha, L., Toespraak te Bank Stasie; kyk ook, Speeches delivered by Gen Botha and Minister at the South African Party Special Congress at Bloemfontein August 1914, p 7.

53. Debates of Both Houses - Fifth and Extraordinary Session, $1914 \mathrm{col} 58$, p 12; Botha, L., Toespraak te Bank.

54. Harcourt Papers, aangehaal deur Louis, W.R., Great Britain and Germany's Lost Colonies 1914-1919, pp 51-52.

55. F.S. Malan ongepubliseerde dagboek Aantekeningen, Mei 1910 - September 1914, "De Brits - Duitse Oorlog."

56. Debates of Both Houses of Parliament, Fifth and Extraordinary Sessions 1914, vols $112-4,25$.

57. Hancock W.K., en Van der Poel, J. (red), Selections from the Smuts Papers III (Smuts - Merriman, 2 Oktober 1914) p 202. 